\title{
SECULARISM AT SCHOOLS AS A TOOL FOR SOCIAL INTEGRATION:THE APPROACH OF THE EUROPEAN COURT OF HUMAN RIGHTS
}

DOI: $\quad 10.24193 /$ SUBBiur.66(2021).1.2

Data publicării online:

25.06.2021

\section{Adam JAKUSZEWICZ*}

'Equality means equal concern and respect across difference. It does not presuppose the elimination or suppression of difference. Respect for human rights requires the affirmation of self, not the denial of self. Equality therefore does not imply a levelling or homogenisation of behaviour but an acknowledgment and acceptance of difference. ${ }^{1}$

\begin{abstract}
When examining the cases on freedom of religion in the field of education, the European Court of Human Rights increasingly adopts the conception of hard or republican secularism. This approach has far-reaching implications for the Court's understanding of social integration as a legitimate ground for the restriction on individual's freedom. The judgement in Osmanoğlu and Kocabaş v. Switzerland and the cases on wearing of religious attire at school demonstrate that despite its claim to neutrality, the republican conception of secularism has its inherent presuppositions about what society should look like and which values such a society

* Adam Jakuszewicz, Doctor in Juridical Sciences, assistant professor at Kazimierz Wielki University in Bydgoszcz, Poland, jakuszewicz@ukw.edu.pl, https://orcid.org/0000-00027094-5822.

${ }^{1}$ South African Constitutional Court case - Coalition for Gay and Lesbian Equality v. Minister of Justice (CCT11/98) [1998] ZACC 15; 1999 (1) SA 6; 1998 (12) BCLR 1517 (October 9, 1998): 1517, 1574-1575.
\end{abstract}


should embrace. In consequence, the application of this conception results in standardisation and homogenisation of the society according to secular and thus nonneutral ethos. This outcome is difficult to reconcile not only with equal respect for individual freedom of religion and moral autonomy, but also with general principles underlying its axiological structure, such as pluralism, tolerance, and broadmindedness.

Keywords: freedom of religion, social integration, republican secularism, liberal-pluralist secularism, religious diversity.

Table of Contents

I. Introduction 16

II. Opposing conceptions of secularism 18

III. Assimilationist integration and republican secularism in school environment in the jurisprudence of the Court before the judgment in Osmanoğlu and Kocabaş $v$.

Switzerland.

IV. Forced integration at the expense of freedom of religion - the case Osmanoğlu and Kocabaş v. Switzerland 25

V. An alternative approach. Respect for diversity as the basis for social integration . 34

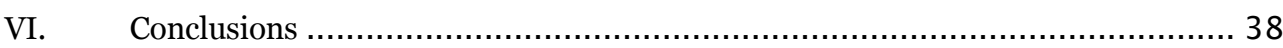

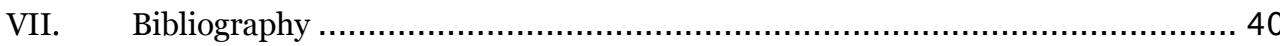

\section{Introduction}

In the jurisprudence of the European Court of Human Rights (hereinafter: the Court) on freedom of religion, in the area of education, considerable importance has been ascribed to the need of social integration of ethnic and religious minorities. According to the Court, this need can be met only through the implementation in the school setting of the principle of secularism. Although this principle is not explicitly laid down in the European Convention on Human Rights (hereinafter: the Convention), it has been 
regarded by the Court as one of the cornerstones of its axiological construction. As a result, it has been viewed as an essential factor that determines the interpretation of the freedom of religion as enshrined in Article 9 of the Convention. At the same time, the Court's assumptions on the meaning of secularism determines their understanding of the notion of social integration and cohesion as a legitimate ground for restricting the individual's freedom of religion.

Given the ambiguity inherent in the very notion of secularism, the Court accepts the meaning of this term which is derived from the constitutional tradition of the respondent state. Such an approach is an inevitable outcome of the Court's extensive use of the doctrine of margin of appreciation with regard to cases concerning the alleged breach of Article 9. Nevertheless, as it will be shown, the Court seems to be increasingly inclined to place the principle of secularism in its 'hard' or republican version above the protection of freedom of religion and beliefs, which results in narrowing the very scope of this right. Indeed, due to the use of the margin of appreciation the principle of secularism has been put by the Court on a pedestal in the sense that the Court accepts that the substance and scope of the freedom of religion is determined by that principle or even is 'subordinated' thereto ${ }^{2}$.

The objective of this paper is to discuss how the Court's particular understanding of secularism and social integration affects the interpretation of freedom of religion in the area of education. In this context, special

2 S.A. Fernández PARRA, El margen nacional de apreciación y el contenido de la libertad de pensamiento conciencia y religión en el Convenio Europeo de Derechos Humanos, 'Eunomía. Revista en Cultura de la Legalidad' 2019, no 17, p. 89. 
attention will be paid to the judgment in the case Osmanoğlu and Kocabaş $v$. Switzerland ${ }^{3}$ (hereinafter: Osmanoğlu) where the Court explicitly endorsed the view of national authorities that social integration through homogenisation of the society, according to the prevailing secular values and patterns of behaviour constitutes a legitimate aim of social policy that justifies imposing far-reaching restriction on religious freedom of parents and schoolchildren. It will also be shown that the frequent adoption of the 'republican' or 'hard' conception of secularism by the Court results in troubling curtailment of concrete individual freedom for the sake of upholding abstract and general principles of social policy, which can hardly be reconciled with rights of religious and ethnic minorities and the selfproclaimed adherence of the Court to pluralism, tolerance and broadmindedness as fundamental values of the development of a democratic society.

\section{Opposing conceptions of secularism}

Before embarking on the analysis of the relevant case-law of the Court it is necessary to give a thought to the meaning of the notion of secularism. An insightful analysis of this concept has been propounded by J. Maclure and C. Taylor 4 . The authors distinguished two broad conceptions of secularism that represent polar opposites, i.e. the 'liberal-pluralist' and the 'republican' one5.

3 Osmanoğlu and Kocabaş $v$. Switzerland, no 29086/12. ECHR 2017, ECLI:CE:ECHR:2017:0110JUD002908612.

4 J. Maclure, C. TAYlor, Secularism and freedom of conscience, Harvard University Press, Cambridge 2011, passim.

5 Ibidem, p. 28. 
Under the 'liberal-pluralist' conception of secularism religion is viewed on equal footing with non-religious beliefs as an enriching and important element of cultural heritage of a country. Consequently, its adherents are prone to permit religious distinctiveness and diversity in public space. They argue that the effacement of religious and ethnic differences from the public space with a view to enhancing civic integration would not only be unnecessary but above all counterproductive. This objective can be achieved more effectively through acknowledgement and respect of similarities and differences between people of diverse backgrounds, which is possible through dialogue, mutual understanding, and cooperation. Furthermore, under the 'liberal-pluralist conception the value of secularism is only instrumental as it serves to guarantee respect for the equal moral value of the individual autonomy and the possibly wide protection of freedom of conscience and religion to all concerned. These values provide legitimacy for establishing the institutional arrangements, such as the separation of church and state and state's religious neutrality or 'functional agnosticism', as J. Maclure and C. Taylor put it, which are not ends in themselves, but are rather envisaged to serve the purpose of enabling the equal realisation of various conceptions of the good life without favouring or promoting any of them ${ }^{6}$.

In contrast, under the conception of 'republican' secularism secular arrangements are viewed as a primary instrument for achieving social integration defined as 'allegiance to a common civic identity and the collective pursuit of the common good'7. The adherents of this conception (mis)perceive

${ }^{6}$ Ibidem, p. 27-35. Similarly, the principle of separation of powers lacks an intrinsic value. It is rather established to prevent tyranny and enhance individual freedom.

7 Ibidem, p. 31. 
religiosity as a 'radical' attitude that is disruptive to the public order, and integration of minorities, as well as counterproductive to the realisation of human rights ${ }^{8}$. For this reason, they argue that the attainment of national unity and social cohesion requires the effacement or neutralization of religion, ethnicity, and other identity markers from public space, regardless of whether they are exposed on the initiative of public authorities or individuals. They also in principle deny any appeals for accommodation (such as exemptions from, or adaptation of, regulations and norms of general application) made on the grounds of religious duties. As a result, secularism in its 'republican' version becomes an intrinsic value, which implies that full separation between church and state or the state's religious neutrality assumes greater importance than respect for freedom of conscience and religion9. Such prioritisation of secularism has rightly been depicted as 'fetishism of means' ${ }^{10}$, i.e. the phenomenon where institutional arrangements are 'defended at all cost rather than means that, though essential, are to be defined as a function of the ends they serve'11.

Within the republican conception of secularism the school is portrayed as 'sanctuaire républicain' (a republican sanctuary) that must be defended 'in order to preserve equality during the acquisition of values and knowledge in girls and boys' and to protect the children from being exposed 'to the bad

${ }^{8}$ G. Du Plessis, The European Struggle with Religious Diversity: Osmanoğlu and Kocabaş v. Switzerland, 'Journal of Church and State' 2018, vol. 6o, issue 3, p. 508.

9 MACluRe, J., \& TAYLOR, op. cit., p. 28.

10 Ibidem, p. 29.

11 Ibidem, p. 29. 
winds that divide, separate and bring us into conflict with one another'12. This vision of school has been put into practice by states that adopt the 'republican' version of secularism and endorsed by the Court which, as the subsequent section will show, is tantamount to approving forced (assimilationist) integration resulting in deplorable curtailment of the freedom of religion, pluralism and cultural diversity.

III. Assimilationist integration and republican secularism in school environment in the jurisprudence of the Court before the judgment in Osmanoğlu and Kocabaş v. Switzerland

The Court implicitly adopted the homogenising or assimilationist approach to social integration in some cases regarding the importance of education to social cohesion that were decided before the leading judgment in Osmanoğlu. Special interest in this context deserves the decision in the case Konrad v. Germany ${ }^{13}$ concerning the consistency with the Convention of the legal ban on home-schooling. The Court subscribed to the view of the German Constitutional Court that the society has an interest in avoiding the emergence of parallel societies based on separate philosophical convictions and the importance of integrating minorities into society'14. Furthermore, the

12 Discours de M. Jacques CHIRAC, Président de la République, sur le respect du principe de laïcité dans la République, Paris le 17 décembre 2003, https://www.elysee.fr/jacqueschirac/2003/12/17/discours-de-m-jacques-chirac-president-de-la-republique-sur-le-respectdu-principe-de-laicite-dans-la-republique-paris-le-17-decembre-2003 (accessed: 20.01.2021). 13 Konrad v. Germany (dec.), no. 35504/03, ECHR 2006, ECLI:CE:ECHR:2006:0911DEC003550403.

14 Ibidem, p. 7. 
Court held that the protection of this interest is consistent with its own jurisprudence on the importance of pluralism for the development of a democratic society ${ }^{15}$. The cited statement 'surely smacks of political correctness (...) and appears to fall squarely under the axe of indoctrination which (...) is unqualifiedly condemned by Protocol 1, Article 2 of the European Convention'16. It is noteworthy that the Court did not explain how they understand the concept of 'a parallel society' and why its formation should be regarded as perilous to the maintenance of the constitutional order. One may ask, for instance, whether Catholic nuns or monks who wish to follow their spiritual vocation and for this purpose establish a convent or a monastery form an undesirable 'parallel society' or whether a group of people with ecologic mind-set who wish to live 'according to nature' and for this purpose establish an ecologic, self-sufficient village should be prevented from doing so in the name of social integration. The use of ambiguous and vague concepts, such as the notion of a 'parallel society' in the reasoning of the Court without clarification of their intended meaning undoubtedly obfuscates the legal discourse and communication between the Court, parties to the proceeding and the public.

The Strasbourg Court's approach to the ban on home-schooling based on majoritarian and homogenising vision of social integration stands in contrast to the approach adopted by the U.S. Supreme Court in the case

\footnotetext{
15 Ibidem.

16 J. Warwick Montgomery, The Justification of Homeschooling Vis-A-Vis the European Human Rights System, p. 7. 25th IVR World Congress Law Science and Technology, Frankfurt am Main 15-20 August 2011. Paper Series No. 085 / 2012 Series B Human Rights, Democracy; Internet/intellectual property, Globalization, Frankfurt am Main 2012., https://madalen.files.wordpress.com/2013/12/ivr world congress 2011 no 085.pdf. (accessed: 27.01.2021).
} 
Wisconsin $v$. Yoder ${ }^{17}$. The complainants were members of the Amish community who sought the exemption for their children from the last two years of compulsory education as they regarded it detrimental to their religious upbringing. When examining the case, the Supreme Court showed a very considerate attitude towards the religious needs of the Amish community. It noted that 'Compulsory school attendance to age 16 for Amish children carries with it a very real threat of undermining the Amish community and religious practice as they exist today; they must either abandon belief and be assimilated into society at large or be forced to migrate to some other and more tolerant region ${ }^{18}$ '. The Supreme Court also rejected the argument of the state authorities that additional two years of modern education beyond $8^{\text {th }}$ grade are necessary to prepare citizens to participate effectively and productively in America's political system. An important circumstance the Supreme Court considered when ruling in favour of the complainants was the fact that the Amish succeed in preparing their high school age children to be productive members of their community and that they have an excellent record as law-abiding and generally self-sufficient members of society ${ }^{19}$.

Even if one rightly criticises the judgment in Wisconsin $v$. Yoder for focusing exclusively on the interests of parents and Amish community and completely ignoring the children's interest in receiving an appropriate education that would open more options for their future choices ${ }^{20}$, one should

\footnotetext{
17406 U.S. 205 (1972).

18 Ibidem, p. 218.

19 Ibidem, p. 212 et seq.

20 E. Bartholet, Homeschooling: Parent Rights Absolutism vs. Child Rights to Education \& Protection, 'Arizona Law Review' 2020, vol. 62: 1, p. 31.
} 
concede that the Supreme Court was right in attributing a high value to the respect for pluralism and diversity. The Supreme Court's approach is even more telling when one considers that in the U.S. the interest in nation building and civic integration was one of the most important reasons for which nearly every state enacted mandatory school attendance laws by the end of World War I ${ }^{21}$.

In turn the assumption of the 'republican' or 'hard' secularism underlies the reasoning of the Court in numerous cases concerning the ban on wearing of religious symbols, in particular headscarves, by pupils and students in the school setting. The Court observed that in France, Turkey and Switzerland secularism is 'a constitutional principle, and a founding principle of the Republic, to which the entire population adheres and the protection of which appears to be of prime importance, in particular in schools' ${ }^{22}$. For this reason, the Court concluded that attitudes contrary to that principle cannot be regarded as a manifestation of a religion and therefore are not protected under Article 9.1 of the Convention ${ }^{23}$. Moreover, the Court observed that it is to the national authorities 'to take great care to ensure that, in keeping with the principle of respect for pluralism and the freedom of others, the manifestation by pupils of their religious beliefs on school premises did not take on the nature of an ostentatious act that would constitute a source of

${ }^{21} \mathrm{~K}$. T., BURGESS, The constitutionality of home education statutes, 'UMKC Law Review' 1986, no 55, p. 70. In the words of the US Supreme Court, public education was deemed the most powerful means of 'promoting cohesion among a heterogeneous democratic people'. (McCollum v. Board of Educ., 333 U.S. 203, 216 (1948.).

22 Dogru v. France, no. 27058/05, § 72, ECHR 2009, ECLI:CE:ECHR:2008:1204JUD002705805.

23 Ibidem. 
pressure and exclusion'24. Leaving apart both the ambiguity of the phrase 'attitudes contrary to the principle of secularism' and the fact that the national authorities have never convincingly proven that wearing religious attire constitutes 'a source of pressure and exclusion', it is noteworthy that the Court explicitly placed the principle of secularism above the right to freedom of religion.

\section{Forced integration at the expense of freedom of religion - the case Osmanoğlu and Kocabaş v. Switzerland}

The case where the Court explicitly referred to the integration function of school within the republican-secularist concept of social cohesion is the already mentioned judgment in Osmanoğlu and Kocabaşv. Switzerland. The case concerned the objection of Muslim parents to their daughters' attending compulsory mixed swimming classes. The applicants justified their objection on the grounds that they are responsible for inculcating in their children modesty requirements mandated by their religion which they are supposed to observe after reaching the puberty. The Government submitted that the interference with the applicants' freedom of religion was justified by the need of integration and adaptation of children from different cultural backgrounds to the Swiss lifestyle in order to ensure their equal future participation in the economic, social and cultural life of the country ${ }^{25}$. They contended that given

24 Ibidem, $\S 72$. The same arguments have also been advanced in the following admissibility decisions: Aktas v. France (no. 43563/o8), Bayrak v. France (no. 14308/o8), Gamaleddyn $v$. France (no. 18527/o8), Ghazal v. France (no. 29134/o8), J. Singh v. France ( no. 25463/o8) and R. Singh v. France (no. 27561/o8). All of them were issued on 30 June 2009.

25 Osmanoğlu and Kocabaş v. Switzerland, op. cit., § 70. 
the rapidly increasing Muslim population in Switzerland the importance of integration and respect for the values of the local culture should be attached more weight than it was the case in the past ${ }^{26}$. The Government also indicated that the interference with the religious freedom of the applicants was diminished by the fact that their daughters could use a burqini during the swimming lessons, which they refused because of the fear of stigmatisation of their children. Moreover, the Government pointed out to the fact that in the school there were separate cloakrooms and showers for boys and girls, so the applicants' daughters did not have to undress in the presence of students of opposite $\operatorname{sex}^{27}$.

It is important to note that the applicants did not question the importance of social integration of immigrants. They rather argued that the exemption they sought would to a greater extent serve that objective than the policy adopted by the Government. In their view, when a host country is tolerant of religious beliefs of minorities, foreigners are more willing to integrate into the local society and accept its rules. The applicants also contended that in their case the measures aimed at integration were not at all necessary, since they had been living in Switzerland for decades and felt more connected to that country than to the country of their origin. They declared that they respect the constitutional principles and legal order of their host country and pointed out that the only feature that distinguished them from the majority of the Swiss population was their religion ${ }^{28}$. Furthermore, the applicants claimed that the mere fact that their children do not attend

\footnotetext{
${ }^{26}$ Ibidem, § 69 .

27 Ibidem, § 76.

${ }^{28}$ Ibidem, § 60 .
} 
swimming classes does not marginalise them. Given that these classes constituted only a relatively small fraction of the course in physical education, the pupils' socialisation occurs mainly in other school contexts. Lastly, according to the applicants in the case of their daughters the educational objective of swimming lessons was not endangered either since they were taking private swimming lessons.

The Government did not accept these arguments and insisted that attending private swimming lessons instead of those given by the school merely leads to isolation of the children. They also contended that the achievement of the educational objectives of the classes hinges not only upon their learning content but also upon the conditions in which they take place ${ }^{29}$. According to the Government swimming classes are intended not only to teach learners to swim but also, what is even more important, to fulfil the function of socialisation and integration. The Government also submitted that it was common in Switzerland to see partly naked bodies on beaches and in the media so that children should learn from an early age 'to handle' these aspects of community life in order to facilitate their functioning in society ${ }^{30}$.

The Court endorsed the arguments advanced by the Government and found no breach of Article 9 of the Convention. In particular, the Court shared the Government's view that the objective of obligatory swimming lessons 'was the integration of foreign children from different cultures and religions, as well as the smooth functioning of the education system, compliance with compulsory schooling and equality between the sexes. In particular, the measure was intended to protect foreign pupils from any form of social

29 Ibidem, $\S 75$.

30 Ibidem, $\S 77$. 
exclusion'31. The Court also emphasised the important role of public schools in the process of social integration into local customs and way of life and concluded that the applicants' daughters' interest in receiving education that facilitates their integration 'according to local customs and mores' outweighs the parents' wish to have them exempted from mixed swimming lessons ${ }^{32}$.

The judgement of the Court in Osmanoğlu is problematic for several reasons. Above all, given that the judgment lacks a concrete in-depth analysis of the suitability and role of swimming classes for achieving pupils' social integration and preventing their social exclusion, the proper examination of the proportionality requirement is missing. In particular, the Court did not address the applicants' argument that their family was well integrated into Swiss society and that only their religion distinguishes them from the rest of the population. Nor did the Court consider that swimming classes represented only an ancillary part of the school curriculum. Similarly, the Court did not consider the fact that the applicants' requests to transfer their daughters to another school in the same city where there were no swimming classes in the curriculum were turned down. The need for applicants' integration into society has therefore not been convincingly proven neither by the respondent Government nor by the Court. In cases like Osmanoğlu national authorities should be required to indicate a specific threat to social integration or other interest of the child that might be sacrificed because of his or her exemption from a specific course or part of it. Mere reference to the vague and imprecise need of 'social integration' should be regarded as insufficient for limiting a human right. In other words, to meet the condition of proportionality, the

${ }^{31}$ Ibidem, $§ 65$.

32 Ibidem, § 97. 
Court should require concrete evidence that the attendance at swimming classes is a sine qua non for social integration or that the applicants' daughters were not enough integrated or in need of further integration. Moreover, it is hard to believe that granting an exemption from swimming classes would violate the interests of the applicants' daughters or other persons (potentially) involved, i.e. the other pupils, teachers and the school in general. In sum, the Court seems to perceive freedom of religion on equal footing with policy decisions of the respondent state regarding education and social integration.

Furthermore, the Court has adopted 'a non-neutral secularist understanding and assumption of social integration above different understandings thereof without adequate justification and proof that the same level of social integration cannot be achieved by less restrictive means. In other words, the Court assumed 'that there is only one correct form of social integration, i.e. the one which emerges as the result of the implementation of strict secularism'33. In such a way the Court has given a green light to the assimilationist policies aimed at cultural 'absorption' of ethnic and religious minorities. This approach is homogenizing in the sense that people from different cultural backgrounds are expected to adapt to the specific country's lifestyle. It 'equates equality with uniformity and denies alternative forms of being co-existing in societies ${ }^{34}$.

It is also noteworthy that the Court perceived local patterns of behaviour (i.e. the practice of wearing skimpy clothes in some contexts) as if they were objective and the only adequate ones. This is inferred from the Court's acceptance of the Government's argument that children have to learn

33 G. Du Plessis, op. cit., s. 508.

34 Ibidem, 509. 
'to handle' the aspects of community life that are incompatible with their parents' religious beliefs. (One might assume that in the context of the commented judgment 'to handle' means to neutralise moral objections against patterns of behaviour deemed reprehensible and to learn to accept them as 'normal'). In such a way the Court accepted one mode of integration without considering whether alternative forms of nation-building exist that do not necessarily imply the formation of a homogeneous society. In normalising prevailing social patterns of behaviour and placing them above the individual's religious convictions, the Court endorsed a non-neutral version of secularism promoted by national authorities. The local customs, however, are mutable and depend on time and place. For instance, fifty years ago it was very rare for states to organise mixed swimming classes and it cannot be ruled out that in the future other activities or practices which are shocking today will be normalised in the name of, say, gender equality. 'If the evolutive local customs and traditions are the ultimate criterion taken into account by the Court to impose practice on parents, how can one live according to deeply-rooted and timeless convictions? It amounts to having to obey zeitgeist 35 '.

What is even more troubling, by declaring coercing a person to make a positive act (e.g. sending their daughters to swimming classes) against their deeply-seated religious convictions by means of administrative sanctions (imposition of fines) compatible with the Convention, the Court endorsed the state's coercive approach to social integration ${ }^{36}$. Forcing someone to act

35 C. FoltZENLOGEL, Integration \& Parental rights, https://eclj.org/religiousfreedom/echr/-rome-on-prend-des-bains-comme-les-romains, (accessed 30.12.2020). ${ }^{36}$ Ibidem. 
against their deep convictions arguably constitutes a further-reaching and more serious interference with the individual's freedom of conscience than preventing someone from acting positively according to their beliefs. For this reason, the interference with religious freedom of the applicants is to be regarded as being of particular intrusiveness, which should have been adequately considered at the proportionality level.

The judgement in Osmanoğlu is therefore 'of assimilationist inspiration'37. Furthermore, it 'strengthens the sanctuarisation of public schools which are becoming a tool for social and cultural standardisation which one then qualifies as 'integration'38.' At the same time, the Court reassigned the role of a school subject as in the light of the judgement in Osmanoğlu the main role of swimming classes is not learning and improving swimming but practising this activity together (despite the fact that swimming is essentially an individual sport). In other words, action in common is perceived by the Court as a tool for generating a form of collective life and common identity.

The commented judgement can also be viewed as a continuation of the Court's tendency to restrict freedom of religion in order to uphold the vague principles of 'living together', allegedly derivable from the concept of 'rights and freedoms of others' under Article 9.2 of the Convention. This trend appeared in the judgement S.A.S. $v$ France ${ }^{39}$ concerning the ban on wearing

37 Ibidem.

${ }^{8}$ Ibidem.

39 S.A.S. v France [GC], no. 43835/11. ECHR 2014, ECLI:CE:ECHR:2014:0701JUDo04383511. 
full veils in public. While in S.A.S and the subsequent similar cases $^{40}$ the notion of 'living together' involved 'the institution of a form of sameness, consisting (...) in the visibility of the face, Osmanoğlu concretises this, and uses the essential ethos of 'living together' as a means of constructing a form of collective life, and one consisting in homogeneity and simultaneity' ${ }^{4}$. Furthermore, Osmanoğlu exemplifies a more general trend in the Court's jurisprudence on freedom of religion that can be described as a progressive moving away from the thorough fact-based assessment of the necessity of restrictions on individual freedom towards reasoning based on abstract principles and creating new and vague legal concepts that allegedly fall within the scope of the notion of 'rights and freedoms of others' under Article 9.2 of the Convention. It is not to say that the facts are irrelevant to the Court, but rather that the emphasis in the Court's reasoning has shifted in favour of more general values, such as the right of states to take their own policy decisions on sensitive matters related to freedom of religion.

This approach of the Court is alarming for many reasons. First of all, appealing to general principles or aims of social policy debilitates the onus on the respondent governments to present a rigorously considered and factbased argumentation that carefully weights the conflicting interests. Secondly, giving more weigh to general values results in the Court's expanding the already extensive application of the margin of appreciation that

40 Belkacemi and Oussar v. Belgium, no. 37798/13, ECHR 2017, ECLI:CE:ECHR:2017:0711JUDo03779813; Dakir v. Belgium, no. 4619/12, ECHR 2017, ECLI:CE:ECHR:2017:0711JUDoo0461912.

${ }^{41}$ S. TROTTER, 'Living Together', 'Learning Together', and 'Swimming Together': Osmanoglu and Kocabas $v$. Switzerland (2017) and the Construction of Collective Life, 'Human Rights Law Review' 2018, vol. 18, Issue 1, p. 15, http://eprints.lse.ac.uk/87226/,_accessed: 12.01.2021). 
traditionally has been wide as far as cases on freedom of religion are concerned. In turn, the overextension of the margin of appreciation 'allows almost complete deference to the State, which has the potential to undermine the religious freedom of minorities'42. It should be borne in mind that decisions that are made on the grounds of margin of appreciation favour majority perceptions of church-state relations and place of religion in public life. In overusing this mechanism, the Court imperils the ability to exercise its supervisory functions around the Convention and its application. In short, it undermines its mandate to protect vulnerable minority populations in Europe ${ }^{43}$.

Osmanoğlu and cases related to freedom of religion in the field of education can be seen as an illustration of the 'struggle with 'radical' religious groups and the fear that they are creating undesirable parallel societies unable to integrate with secular values of Western European countries'44.The perception of a religion, irrespective of its type, as radical is connected with widespread negative connotations to this phenomenon in general. In secularised Europe, religion is often regarded as a repository of obsolete values, bigotry, or fanaticism. Due to terrorist attacks in recent years, this negative perception especially relates to Islam. Militant jihadism is believed to be partly caused by the fact that Muslim immigrants are not integrated into the host countries' societies. Nevertheless, in assuming that religions are 'radical' and dangerous in the sense that they are counterproductive to human

42 S. BERry, Religious Freedom and the European Court of Human Rights' Two Margins of Appreciation, 'Religion and Human Rights' 2017, no 12, p. 207.

43 M. ADRIAN, The principled slope: religious freedom and the European Court of Human Rights, 'Religion, State and Society' 2017, vol. 45, nos. 3-4, p. 175.

44 G. Du Plessis, op. cit., p. 513. 
rights (such as equality of women), 'hard' or 'republican' secularism creates unbridgeable antagonism between secular and religious values. This antagonism in turn is one of the factors which account for the insufficient integration of diverse minority groups into Western societies. Nowadays, this holds true specifically with regard to Muslim communities. Indeed, 'Islam often serves as a canvas on which to project fears surrounding the loss of national, cultural or also religious identity'45. Many cases on freedom of religion resolved by the Court over the last decades where the restriction on individual's rights in the name of 'hard' secularism were deemed legitimate suggest that the Court is not at all immune to such perception of religion.

\section{An alternative approach. Respect for diversity as the basis for social integration}

When examining the alleged breach of Article 9 the Court should adopt the in dubio pro libertate religosa approach or the presumption in favour of individual liberty. Under this approach the individual's freedom should be protected as far as possible and can be limited only if there are unequivocal, convincing arguments justifying the need of adoption of a restrictive measure. In other words, the restriction clause of Article 9.2 of the Convention should be construed narrowly as an exception to the general rule laid down in Article 9.1. This requires applying a strict necessity and proportionality test.

45 F. BRETSCHER, Osmanoğlu and Kocabaş v. Switzerland: A Swiss perspective, 'Strasbourg Observer' 30 March 2017, https://strasbourgobservers.com/category/cases/osmanoglu-andkocabas-v-switzerland/ (accessed: 05.01.2021). A telling example of the prohibition of the construction of minarets, introduced to the Swiss Constitution by popular vote (Art. 72 sec. 3.). 
Moreover, in order to appropriately protect the right to freedom of conscience and religion, whose exercise is intimately linked to the protection of human dignity, the Court should depart from the conception of the republican secularism and shift to the liberal-pluralist one. Due to its role of ensuring equal respect for the conscience of each individual, it is much more legitimate than the republican one which attempts at imposing on individuals a uniform (secular) ethos and system of values. The liberal-pluralist version of secularism is to a greater extent compatible with the enhancement of both individual autonomy, enjoyment of human rights and pluralism. It is also fully compatible with the state's role as 'a neutral and impartial organiser of the exercise of various religions, faiths, and beliefs ${ }^{46^{\prime}}$. These objectives are more important when one considers, on the one hand, the increasing secularisation of European societies and the concomitant insufficient sensitivity to religious needs of some citizens and, on the other, cultural diversification of European societies with growing number of members of various less known or 'exotic' religious movements. As a result of these processes freedom of religion will arguably to a greater extent become a right of minority groups than it was in the past and than it is nowadays.

The liberal-pluralist conception of secularism was assumed by the Court in the case Lautsi $v$. Italy ${ }^{47}$ on the conformity with the Convention of

${ }^{46}$ As the Court rightly noted on many occasions, 'In democratic societies, in which several
religions coexist within one and the same population, it may be necessary to place limitations
on freedom to manifest one's religion or beliefs in order to reconcile the interests of the various
groups and ensure that everyone's beliefs are respected. The Court has frequently emphasised
the State's role as the neutral and impartial organiser of the exercise of various religions, faiths
and beliefs, and has stated that this role is conducive to public order, religious harmony and
tolerance in a democratic society'. (e.g. S.A.S. $v$. France, op. cit., § 127).
47 Lautsi $v$. Italy [GC], no. 30814/O6, ECHR 2011, ECLI:CE:ECHR:2011:0318JUDoo3081406. 
the compulsory display of crucifixes in Italian schools. Admittedly, given the 'preponderant visibility'48 the authorities conferred on the country's majority religion in the school environment, it is at least doubtful that the mandatory display of crucifixes in state schools or offices is compatible with the principle of state neutrality and the principle of secularism, even in its 'weak' liberalpluralist version. Nevertheless, it should be conceded that the endorsement by the Court (guided by the doctrine of the margin appreciation) of the Italian 'liberal-pluralist' approach permitted to examine the contested measure in the broader social context and rendered the judgment at least some legitimacy. Specifically, the Court considered that the presence of crucifixes is not associated with compulsory teaching about Christianity and that school environment is open in parallel to other religions. For instance, it was not forbidden for pupils to wear Islamic headscarves or other symbols or apparel that has a religious connotation. Furthermore, alternative arrangements were possible to help school environment fit in with non-majority religious practices (the beginning and end of Ramadan were 'often celebrated' in schools' optional religious education could be organised in schools for 'all recognised religious creeds'). For these reasons, there was nothing to suggest that the Italian authorities were intolerant of pupils who believed in other religions, were non-believers or who held non-religious philosophical convictions ${ }^{49}$.

Admittedly, the general shift to liberal-pluralist secularism would imply the need to reconsider the role of the margin of appreciation doctrine in the context of overall jurisprudence of the Court on freedom of religion. The

48 Ibidem, $\S 71$.

49 Ibidem, $\S 74$ et seq. 
broad margin of appreciation afforded to national authorities in this field is justified inter alia by the fact that it is not possible to discern throughout Europe a uniform conception of the significance of religion in a society and that the meaning or impact of the public expression of a religious belief differs according to time and context ${ }^{5}$. Consequently, the rules in this sphere vary from one country to another according to national traditions and the requirements imposed by the need to protect the rights and freedoms of others and to maintain public order ${ }^{51}$.

However, given the already mentioned processes of increasing secularisation and cultural diversification across Europe, this argument does not seem as convincing as it was the case in the past. In most European countries the role of religion in public life and the situation of believers with regard to real possibilities of practicing their faith in daily life outside the private sphere in most European countries seems to be getting similar. The rationale for the excessive use of the margin of appreciation has therefore at least debilitated, if not become completely invalid. What is more, the broad application of the margin of appreciation in the area of freedom of religion in increasingly secularised social and political contexts results in relativizing and hollowing its very substance. It also 'allows for preferential treatment of the state and majorities to the detriment of the protection of minorities and individual' 52 .

\footnotetext{
$5^{\circ}$ W. A. Shabas, European Convention on Human Rights. A Commentary, Oxford University Press, Oxford 2015, p. 426.

${ }^{11}$ E.g. S.A.S. $v$ France, op. cit., § 130.

$5^{2}$ M. Lugato, The 'Margin of Appreciation' and Freedom of Religion: Between Treaty Interpretation and Subsidiarity, 'Journal of Catholic Legal Studies', 2013. vol. 52, p. 53.
} 
The shift to liberal pluralist conception of secularism would open up the possibility of the application of the standard of reasonable accommodation as elaborated in the Anglo-Saxon countries. According to this concept, the individual's religious needs or conscientious objections should be accommodated unless it would pose to the involved an undue burden (e.g. an excessive costs to an employer or a considerable threat or detriment to rights and freedoms of others). Furthermore, wherever possible, accommodation or exemption from a legal duty could be compensated with the imposition of an alternative obligation. The function of such an alternative obligation would be to lessen any burden the accommodation might place on the society, as well as to eliminate (the appearance of) a privileged or more advantageous position of the individual exempted from the primary legal duty. For instance, in cases like Osmanoğlu, the parents or school authorities could have considered an alternative solution for achieving the goal of social integration allegedly undermined by the hypothetical exemption from swimming classes, such as attending other optional classes (an art or music club) if offered by the school. Undoubtedly, the approach of reasonable accommodation is more equitable when solving conflicts between freedom of religion and other values in the context of multicultural societies.

\section{Conclusions}

The jurisprudence of the European Court of Human Rights on freedom of religion is moving away from evaluation of the facts to (over)emphasising of general principles and creating vague legal concepts such as 'social integration'. This trend also appears in cases concerning freedom of religion in school environment and manifests in the Court's 
increasing reliance upon the republican secularism and social integration as legitimate grounds for restricting the concrete individual rights. The judgements in Osmanoğlu and cases on wearing religious attire at school demonstrate that, despite its claim to neutrality, the republican secularism has its inherent presuppositions about what society should look like and which values such a society should embrace. In consequence, the application of this conception results in standardisation and homogenisation of the society according to secular and thus non-neutral ethos. This outcome is difficult to reconcile not only with individual rights laid down in the Convention, but also with general principles underlying its axiological structure, such as pluralism, tolerance, and broadmindedness. The Court's overemphasis on general principles and objectives of social policy pursued by national authorities debilitates the requirement of member states to present a solid, fact-based justification of the need to restrict the individual's freedom. It also imperils the effectiveness of the protective function of the Convention, which is especially alarming as far as rights of vulnerable minority groups or groups subject to state authority such as pupils are concerned. These threats could be mitigated, if not completely overcome, if the Court based their interpretation of Article 9 on the liberal-pluralist conception of secularism. As it has been shown, this conception is much more compatible with the Convention values and has a more enhanced potential for ensuring the adequate protection of moral autonomy and freedom of conscience of all concerned in religiously and culturally diversified Europe. 


\section{Bibliography}

M. Adrian, The principled slope: religious freedom and the European Court of Human Rights, 'Religion, State and Society' 2017, vol. 45, nos. 3-4, pp. 174-185.

S. Berry, Religious Freedom and the European Court of Human Rights' Two Margins of Appreciation., 'Religion and Human Rights' 2017, no 12, pp. 198-209.

E. Bartholet, Homeschooling: Parent Rights Absolutism vs. Child Rights to Education \& Protection, ‘Arizona Law Review’ 2020, vol. 62: 1, pp. 2 80.

F. Bretscher, Osmanoğlu and Kocabaşv. Switzerland: A Swiss perspective, 'Strasbourg $\quad$ Observer' $30 \quad$ March 2017, https://strasbourgobservers.com/category/cases/osmanoglu-andkocabas-v-switzerland/, (accessed: 05.01.2021).

Burgess, K. T., The constitutionality of home education statutes, 'UMKC Law Review' 1986, no 55, pp. $69-84$.

Discours de M. Jacques Chirac, Président de la République, sur le respect du principe de laïcité dans la République, Paris le 17 décembre 2003, https://www.elysee.fr/jacques-chirac/2003/12/17/discours-de-m-jacqueschirac-president-de-la-republique-sur-le-respect-du-principe-de-laicitedans-la-republique-paris-le-17-decembre-2003, (accessed: 20.01.2021).

G. Du Plessis, The European Struggle with Religious Diversity: Osmanoğlu and Kocabas, v. Switzerland, 'Journal of Church and State' 2018, vol. 6o, issue 3, pp. 503-525.

S. A. Fernández Parra, 'El margen nacional de apreciación y el contenido de la libertad de pensamiento conciencia y religión en el Convenio 
Europeo de Derechos Humanos, 'Eunomía. Revista en Cultura de la Legalidad' 2019, no 17, pp. 68-99.

C. Foltzenlogel Integration \& Parental rights, https://eclj.org/religiousfreedom/echr/-rome-on-prend-des-bains-comme-les-romains, (accessed 30.12.2020).

M. Lugato. The 'Margin of Appreciation' and Freedom of Religion: Between Treaty Interpretation and Subsidiarity. 'Journal of Catholic Legal Studies' 2013, vol. 52, pp. 49-70.

J. Maclure, C. Taylor, Secularism and freedom of conscience. Harvard University Press, Cambridge, Massachusetts, London 2011.

W. A. Shabas, European Convention on Human Rights. A Commentary, Oxford University Press, Oxford 2015,

S. Trotter, 'Living together, learning together', and 'swimming together':

Osmanoglu and Kocabas v. Switzerland (2017) and the construction of collective life, 'Human Rights Law Review', March 2018, vol. 18, issue 1, http://eprints.lse.ac.uk/87226/ (accessed: 12.01.2021).

J. Warwick Montgomery, The Justification of Homeschooling Vis-A-Vis the European Human Rights System, 25th IVR World Congress LAW SCIENCE AND TECHNOLOGY Frankfurt am Main 15-20 August 2011. Paper Series No. 085 / 2012 Series B Human Rights, Democracy; Internet / intellectual property, Globalization, Frankfurt am Main 2012., https://madalen.files.wordpress.com/2013/12/ivr world congress 2011 n o 085.pdf. (accessed: 27.01.2021). 